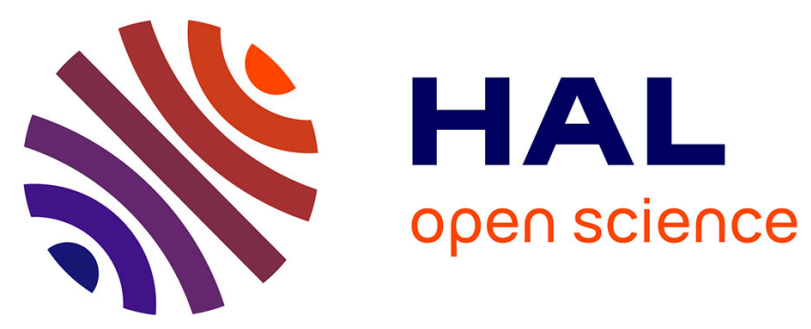

\title{
Arcing test on an aged grouted solar cell coupon with a realistic flashover simulator
}

J.M. Siguier, V. Inguimbert, Gaétan Murat, D. Payan, N. Balcon

\section{To cite this version:}

J.M. Siguier, V. Inguimbert, Gaétan Murat, D. Payan, N. Balcon. Arcing test on an aged grouted solar cell coupon with a realistic flashover simulator. Spacecraft Charging Technology Conference 2014 (13th SCTC), Jun 2014, PASADENA, United States. hal-01081268

\section{HAL Id: hal-01081268 https://hal.science/hal-01081268}

Submitted on 7 Nov 2014

HAL is a multi-disciplinary open access archive for the deposit and dissemination of scientific research documents, whether they are published or not. The documents may come from teaching and research institutions in France or abroad, or from public or private research centers.
L'archive ouverte pluridisciplinaire HAL, est destinée au dépôt et à la diffusion de documents scientifiques de niveau recherche, publiés ou non, émanant des établissements d'enseignement et de recherche français ou étrangers, des laboratoires publics ou privés. 


\title{
Arcing test on an aged grouted solar cell coupon with a realistic flashover simulator
}

\author{
Jean-Michel Siguier, Virginie Inguimbert, Gaël Murat, Denis Payan, Nicolas Balcon
}

\begin{abstract}
We have performed arcing tests on an aged grouted solar cell coupon provided by KIT (JAPAN) under NEDO grant. Aging is simulated by electrons, protons and UV irradiations combined with thermal cycling, corresponding to 10 years in geostationary orbit (GEO).

Arcing tests are performed with a European standard setup implemented with two different flashover simulators. Instead of using a large capacitance corresponding to the missing solar panel surface, we have implemented two more realistic devices: (1) $2.4 \mathrm{~m} 2$ Kapton surface charged in inverted potential gradient (IPG) mode which releases an average flashover current of $6 \mathrm{~A}$

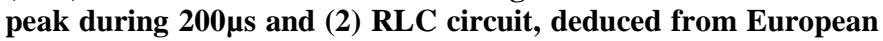
EMAGS3 study (large flashover on $8 \mathrm{~m} 2$ solar array panel). This circuit is connected between the solar array simulator (SAS) line and the surrounding environment with a ring-shape electrode which releases an adaptable flashover current of $5 \mathrm{~A}$ peak during $600 \mu$ s (average values).
\end{abstract}

Results present occurrence of different arc types versus current/voltage SAS values. A comparison is made with other tests, on a similar coupon, performed by U.S. and Japanese labs and also with comparable coupons without grouting.

Keywords-ESD; electrostatic discharge; solar cell; arcing; secondary arc, grouting.

\section{INTRODUCTION}

There are two topics in this paper. The first one is to determine if aged grouting is as efficient as pristine grouting for primary and secondary arcing protection. The second one is to search for a more realistic secondary arcing test setup.

For grouting efficiency after aging issue, our results have to be compared to those of [1] and [2] as a kind of round robin test. Concerning the secondary arcing test setup, the way to take into account the missing part of the solar array is to add a capacitance representing the missing solar cells. But this is not satisfactory because the discharge capacitance current is not representative of the in-flight flashover current, in terms of amplitude and duration: (1) few tenths of A for a discharge capacitance compared to less than 10A for a full solar array, and (2) few tenths of $\mu$ s for a discharge capacitance compared to several hundred of $\mu$ s for actual flashover duration, such as determined in [3].

Therefore, after describing an aged grouted coupon

J-M Siguier, V. Inguimbert and G. Murat are with the Onera - The French Aerospace Lab, F-31055 Toulouse, France

(e-mail: jean-michel.siguier@onera.fr)

D. Payan and N. Balcon are with CNES, F-31401 Toulouse, France provided by KIT (Japan), we will presents two secondary arcing test setups with more realistic flashover simulator. Results are compared to other test campaign performed with the same kind of coupon.

\section{SAMPLE DESCRIPTION}

The coupon is made up with 3 strings of 3 triple junction solar cells where gaps (about $0.5 \mathrm{~mm}$ ) are filled with RTV adhesive grouting and aged with a combination of electrons and protons irradiations plus thermal cycling representing 10 years in GEO (Fig. 1). This coupon and the aging process are very well described in [3].

Visible defect of RTV are cracks, holes and shrinkages in the gaps, discovering partially solar cell edges (Erreur ! Source du renvoi introuvable.).

For these tests, all the metallic parts of the coupon are protected with a $25 \mu \mathrm{m}$ Kapton film except the gap under test.

III. SETUP

\section{A. Facility}

All the tests are performed in the JONAS facility, located at ONERA-Toulouse, which is a $9 \mathrm{~m}^{3}$ vacuum chamber equipped, for these tests, with a plasma source (Kaufmann type) and several measurement devices such as transient current probes and CCD camera.

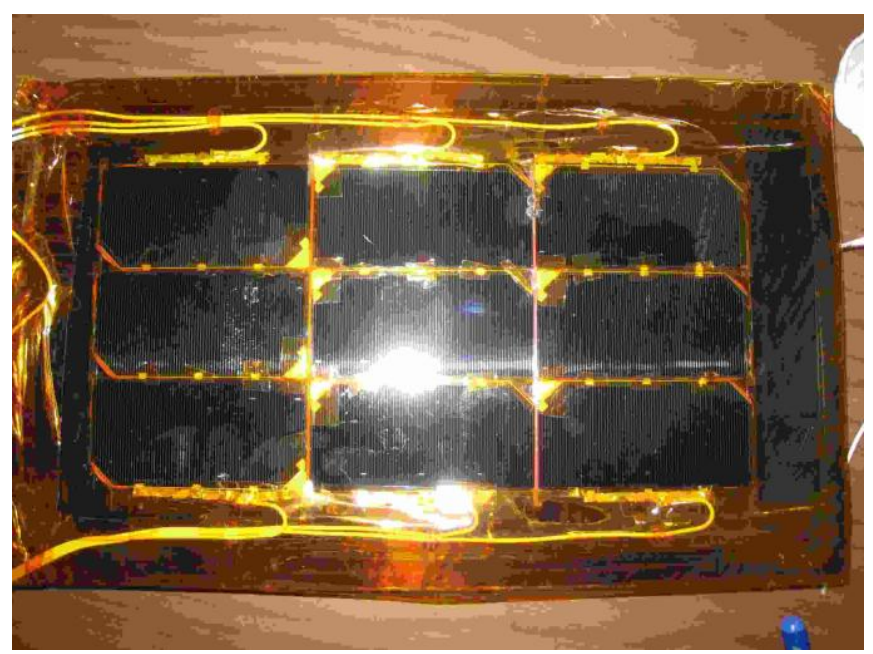

Fig. 1: Tested aged grouted coupon 


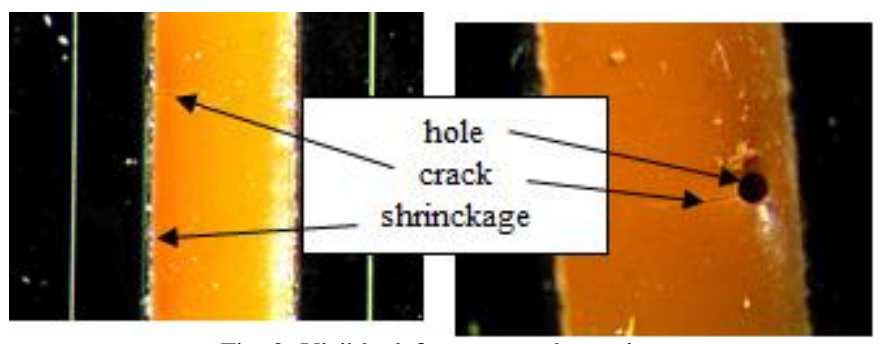

Fig. 2: Visible defects on aged grouting

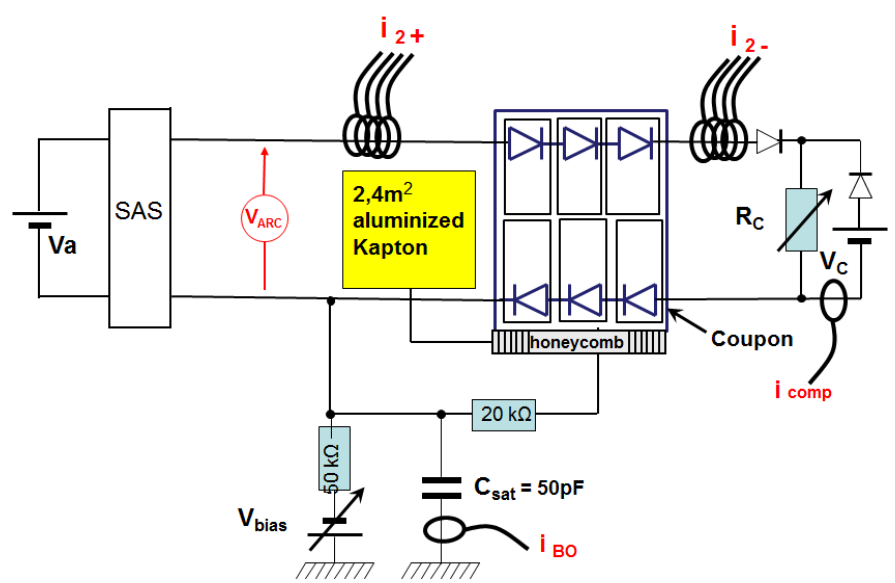

Fig. 3: Test setup with Kapton film as flashover simulator

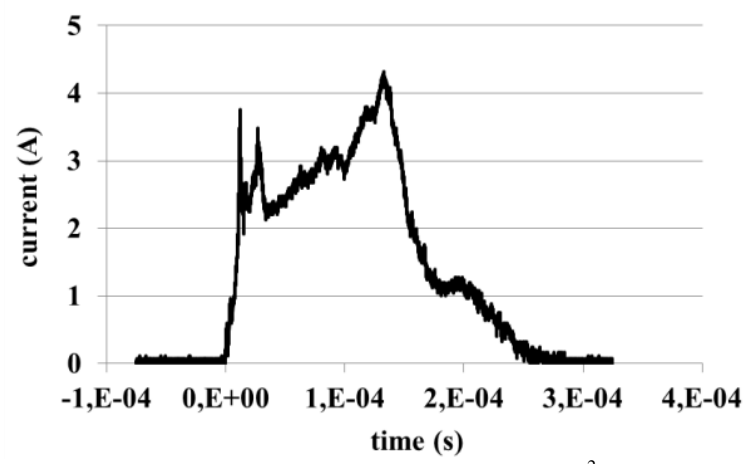

Fig. 4: Example of flashover shape with $2.4 \mathrm{~m}^{2}$ Kapton

\section{B. Flashover simulator is a Kapton film}

This first setup is a typical secondary arc test setup where the missing part of the solar array is simulated by a $2.4 \mathrm{~m}^{2}$ aluminized Kapton surface. Two adjacent solar cell strings are connected to a double solar array simulator (SAS) set to different values. The first SAS is set to $0.6 \mathrm{~A}$ and the second SAS provides the complementary current when a secondary arc starts.

The coupon and the Kapton film are charged in inverted potential gradient (IPG) mode: they are biased with a high voltage source and their surfaces are neutralized with the plasma source. Electrostatic discharges (ESD) or primary arcs are detected with the blow-off current probe $\left(\mathrm{i}_{\mathrm{BO}}\right.$ ). Values of $\mathrm{V}_{\text {arc }}, \mathrm{i}_{2+}$ and $\mathrm{i}_{2-}$ currents indicate the triggering of a secondary arc.

Typical flashover current of this flashover simulator is shown in Fig. 4.

\section{Flashover simulator is a RLC circuit}

In this second setup (Fig. 5), the missing part of the solar array is simulated by a RLC circuit which provides a flashover current between the honeycomb and the coverglasses through a ring electrode set at few $\mathrm{cm}$ of the coupon (Fig. 6). Theoretical flashover current shape is shown in Fig. 7. This flashover simulator has been developed and tested in [3].

As in the first setup, two adjacent strings are connected to a double SAS and the coupon is charged in IPG mode to trigger ESDs and, if so, secondary arcs.

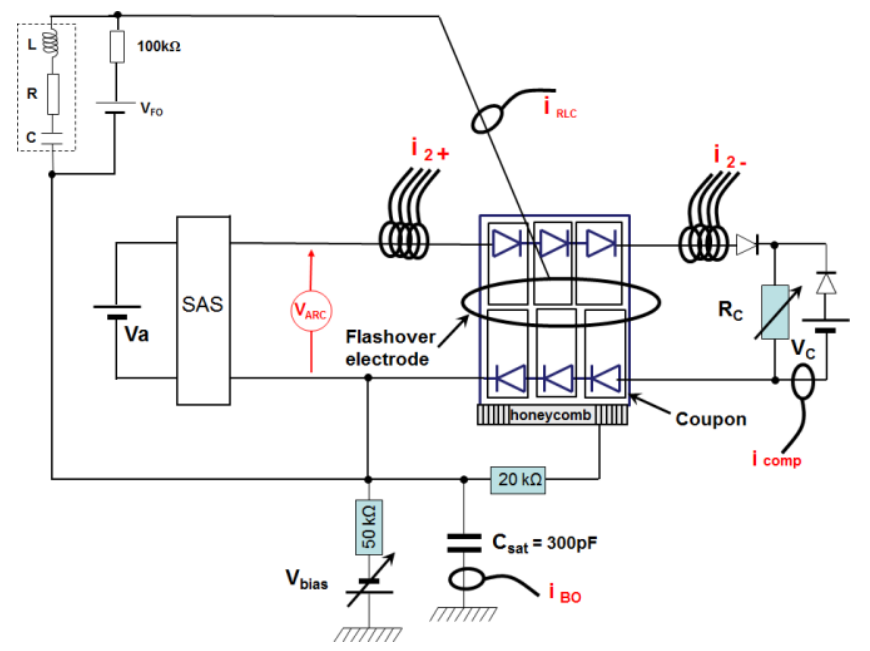

Fig. 5: Test setup with RLC circuit as flashover simulator

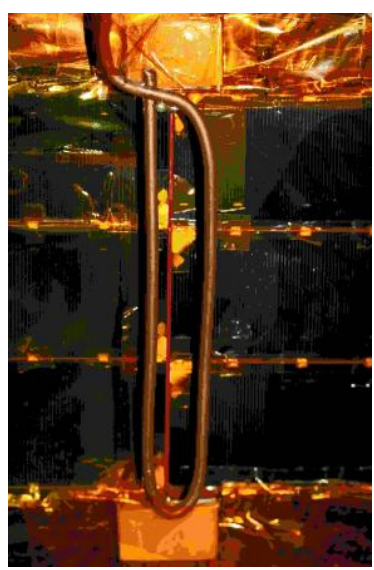

Fig. 6: electrode of the RLC flashover simulator

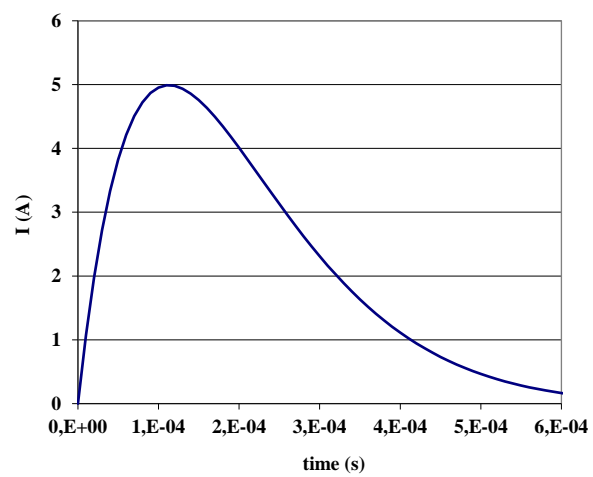

Fig. 7: Example of flashover shape with a RLC circuit 
(Abstract No\# 139)

\section{RESULTS}

\section{A. A Flashover simulator is a Kapton film}

We have recorded several ESD for each SAS step. $V_{\text {bias }}$ is set between $--300 \mathrm{~V}$ and $-1200 \mathrm{~V}$ in order to have a discharge every 10 s approximately.

We began with a first series of tests presented on TABLE 1. We got a lot of primary arcs starting from $\mathrm{V}_{\text {bias }}=-300 \mathrm{~V}$ up to $1000 \mathrm{~V}$. For the three SAS settings, all the primary arcs were located at the same cathodic spot and because there was no unprotected adjacent solar cell edge, no secondary arc can be triggered as we can on Fig. 8. So, we hid with a piece of Kapton tape this spot and started a second test series.

Results are summarized in TABLE 2 where arc type (NSA, TSA or PSA) and maximum arc duration are specified for NSA and TSA.

They show that a PSA occurs at $120 \mathrm{~V}-2.4 \mathrm{~A}$. This PSA, manually stopped after about $1 \mathrm{~s}$, did not create short-circuit in the coupon between the strings and between the string and the honeycomb, so we carried on with the test and got another PSA at 300V-2.4A. Fig. 9 shows current and arc voltage values measured during the first PSA. The effects of the two PSA are visible on Fig. 10.

TABLE 1: Results of first test series. Flashover is Kapton film

\begin{tabular}{|c|c|}
\hline SAS setting & Arc type (maximum duration) \\
\hline 120V-(0.6+1.8)A & 10 ESD with no arc \\
\hline 200V-(0.6+1.8)A & 10 ESD with no arc \\
\hline 300V-(0.6+1.8)A & 20 ESD with no arc \\
\hline
\end{tabular}

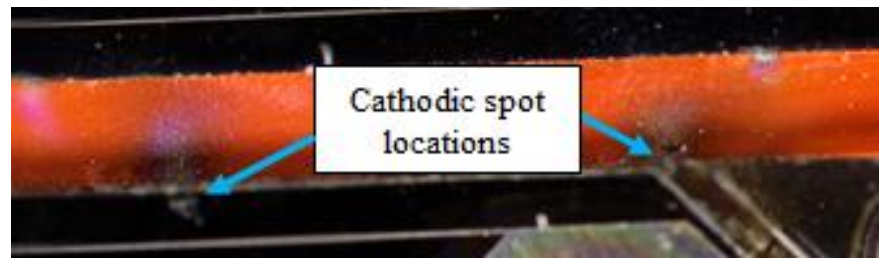

Fig. 8: effect of cathodic spot sputtering of solar cell edge with $600 \mu$ s NSA

TABLE 2: Results of second test series. Flashover is a Kapton film

\begin{tabular}{|c|c|}
\hline SAS setting & Arc type (maximum duration) \\
\hline $\mathbf{1 2 0 V}-(\mathbf{0 . 6 + 1 . 8}) \mathrm{A}$ & $\begin{array}{c}\text { 10 ESD with no arc } \\
\text { 1 PSA }\end{array}$ \\
\hline $\mathbf{2 0 0 V}-(\mathbf{0 . 6 + 1 . 8}) \mathrm{A}$ & 10 ESD with no arc \\
\hline $\mathbf{3 0 0 V}-(\mathbf{0 . 6 + 1 . 8}) \mathrm{A}$ & $\begin{array}{c}\text { TSA }(280 \mu \mathrm{s}) \\
\text { 1 PSA }\end{array}$ \\
\hline
\end{tabular}

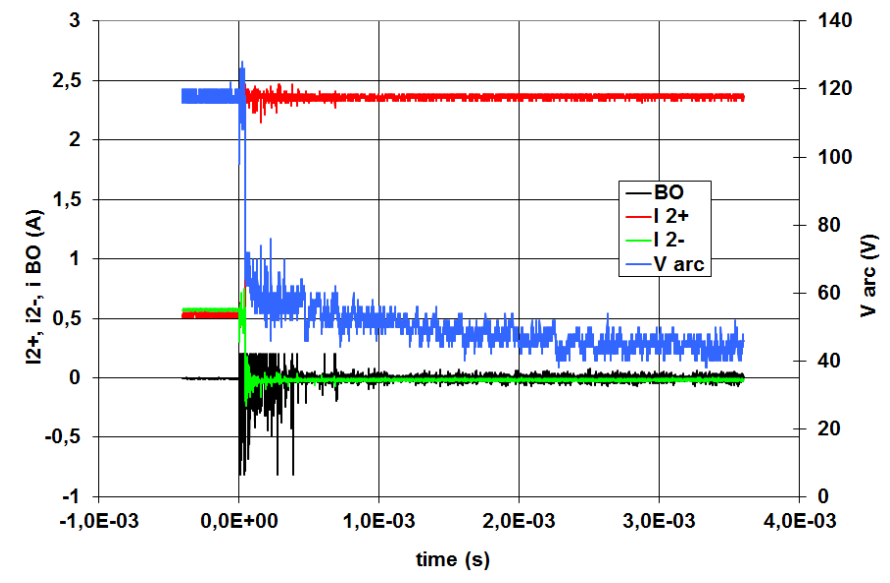

Fig. 9: current and arc voltage values during a TSA

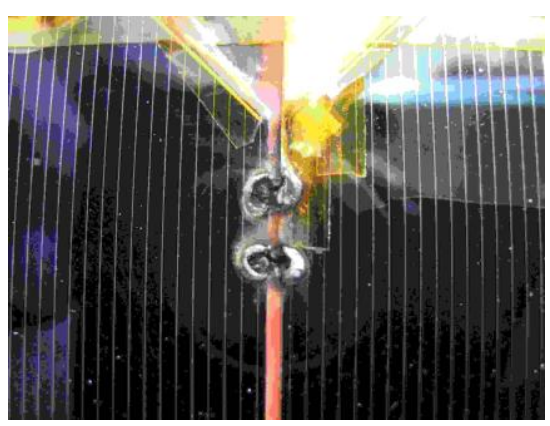

Fig. 10: picture of the two PSA on the grouted coupon

TABLE 3: results of arc discharge. Flashover is a RLC circuit

\begin{tabular}{|c|c|c|c|c|}
\hline SAS values & \multicolumn{4}{|c|}{ Arc types (maximum duration) } \\
\hline $60 \mathrm{~V}-0,6 \mathrm{~A}$ & & $5 \mathrm{NSA}(580 \mu \mathrm{s})$ & & \\
\hline $120 \mathrm{~V}-0,6 \mathrm{~A}$ & 2 no arc & 4 NSA $(600 \mu \mathrm{s})$ & & \\
\hline $180 \mathrm{~V}-0,6 \mathrm{~A}$ & & $5 \mathrm{NSA}(650 \mu \mathrm{s})$ & & \\
\hline $240 \mathrm{~V}-0,6 \mathrm{~A}$ & & $5 \mathrm{NSA}(630 \mu \mathrm{s})$ & & \\
\hline $120 \mathrm{~V}-0,6+0,4 \mathrm{~A}$ & & 2 NSA $(680 \mu \mathrm{s})$ & $3 \mathrm{TSA}(1,25 \mathrm{~ms})$ & \\
\hline $120 \mathrm{~V}-0,6+1,4 \mathrm{~A}$ & & $1 \mathrm{NSA}(580 \mu \mathrm{s})$ & 4 TSA (320ms) & \\
\hline $180 \mathrm{~V}-0,6+1,4 \mathrm{~A}$ & & & 5 TSA (190ms) & \\
\hline $240 \mathrm{~V}-0,6+1,4 \mathrm{~A}$ & & & $5 \mathrm{TSA}(600 \mathrm{~ms})$ & \\
\hline $60 \mathrm{~V}-0,6+2,4 \mathrm{~A}$ & 5 no arc & & & \\
\hline $120 \mathrm{~V}-0,6+2,4 \mathrm{~A}$ & & & & 1 PSA \\
\hline
\end{tabular}

\section{B. Flashover simulator is a RLC circuit}

For this test, we have used the other gap, still pristine, of the same coupon, after removing the part of cells in shortcircuit with the honeycomb.

We have triggered 5 ESD for each SAS step. $V_{\text {bias }}$ is set between $-500 \mathrm{~V}$ and $-1000 \mathrm{~V}$ for the same reasons as the first setup. All the results are summarized in TABLE 3. PSA occurs at $120 \mathrm{~V}-2.4 \mathrm{~A}$, short-circuiting the cells and the honeycomb. Fig. 11 shows current and arc voltage values measured during this PSA. 


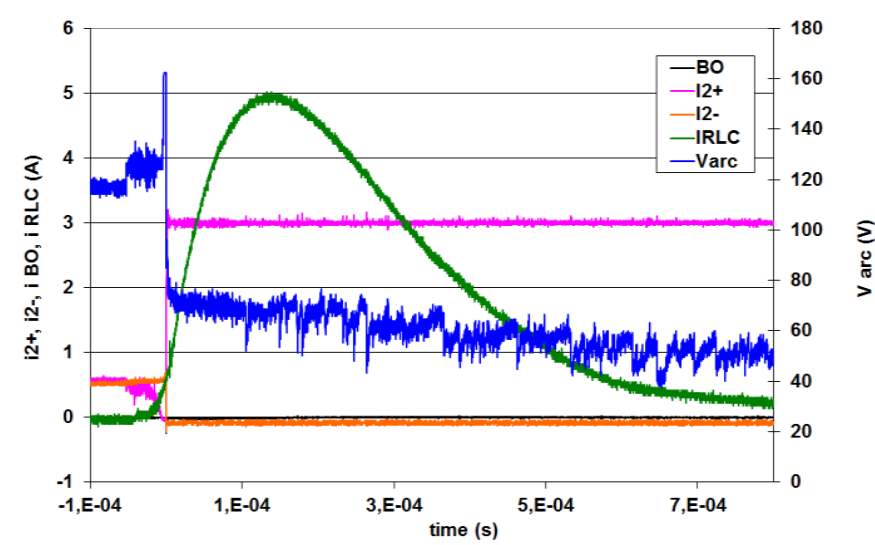

Fig. 11: current and arc voltage values during the beginning of a TSA

TABLE 4: arcing test results of different labs

\begin{tabular}{|c|c|c|}
\hline Lab. & SAS & $\begin{array}{c}\text { Arc type } \\
\text { (maximum duration) }\end{array}$ \\
\hline KIT [1] & $100 \mathrm{~V}-2.4 \mathrm{~A}$ & TSA (66ms) \\
\hline NASA-GRS [2] & $100 \mathrm{~V}-2.2 \mathrm{~A}$ & TSA (>2.6ms ?) \\
\hline ONERA & $120 \mathrm{~V}-1 \mathrm{~A}$ & TSA (1.25ms) \\
(this work) & $120 \mathrm{~V}-2 \mathrm{~A}$ & TSA (320ms) \\
& $120 \mathrm{~V}-2.4 \mathrm{~A}$ & PSA \\
\hline
\end{tabular}

\section{DISCUSSION}

The interest to be as realistic as possible for secondary arcing test was born when we find that it was possible to have large flashovers on complete solar panel surfaces [3] and that it was not satisfactory to simulate the corresponding amount of charges released by a capacitance added to the satellite capacitance $\mathrm{C}_{\text {sat }}$ because it supposes a flashover peak current of several tenth of Amperes. The two flashover simulators presented here are approaches to go in this way.

Another point is, if an arc is triggered, as long is the flashover as long is the arc (NSA). Of course it can be longer (in the case of TSA or PSA). Even if we do stop the arc, it will restart if flashover current still carries on [4]. It is then interesting to reproduce this long duration primary arc. As a consequence, even NSA, which may last $600 \mu \mathrm{s}$, provoke visible degradations like solar cell sputtering as seen on Fig. 8. Of course in the case of accumulation of NSA and TSA, degradations are worst (see Fig. 12) particularly if TSA last $600 \mathrm{~ms}$.

Nevertheless, the fact that flashover last a longer time does not seem to favor PSA occurrence as shown on TABLE 4 which compares our results with the two other labs which have tested the same grouted and aged coupon. Even though, these labs did not reach PSA, they have got quite long TSA for SAS values close or similar to ours despite the fact that blow-off current is very small (5A peak during $20 \mu$ s for [1]).

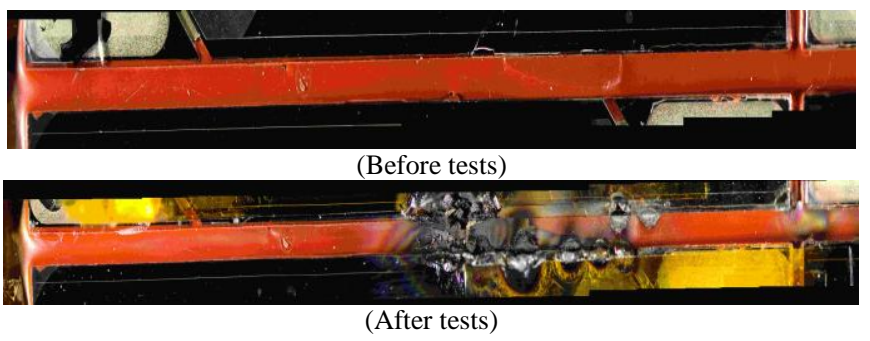

Fig. 12: picture of a part the gap before and after approximately 10 TSA (Gap width enhanced)

\section{SUMMARY}

We have performed secondary arcing tests on an aged grouted solar cell coupon using two kinds of flashover simulators providing current peak and duration corresponding to the discharge of a complete solar array surface and so, more realistic than a discharge capacitance.

Results show that aged grouted coupon is not protected from primary arc because aging uncover large parts of solar cell edges. Secondary arcs (NSA) occur at relatively low SAS value (60V-0.6A). Sustained arcs (TSA) are triggered at higher SAS value (120V-1A) and permanent arc (PSA) is established for a SAS value of $120 \mathrm{~V}-2.4 \mathrm{~A}$.

There is no discrepancy with other labs tests performed on the same aged grouted coupon considering they have got TSA for the same SAS values.

Considering these results, our flashover simulators do not favor PSA occurrence even though all arc durations is several hundred of $\mu$ s.

\section{ACKNOWLEDGMENT}

Thanks to KIT (Japan) for providing aged grouted solar cell coupon obtained under NEDO grant.

\section{REFERENCES}

[1] T. Endo, T. Wada, H. Masui, K. Toyoda and M. Cho, "Effect of Aging on Discharge Tolerance of Grouted Solar Array Panels Confirmed by Simulated Space Environment" , 11th SCTC conf., Albuquerque, September 20-24, 2010

[2] B. Wayner,and J. T. Galofaro, "Inception and prevention of sustained discharges on solar arrays", IEEE Transl. Plasma Science, vol. 40, NO. 2, pp. 388-393, February 2012

[3] V. Inguimbert, P. Sarrailh, J-C. Mateo-Velez, J-M. Siguier, C. Baur, B. Boulanger, A. Gerhard, P. Pelissou, M. Sevoz and D. Payan, "Measurement of the Flashover Expansion on a Real Solar Panel - Preliminary Results", IEEE Transl. Plasma Science, vol. 41, NO. 12, pp. 3370-3379, December 2013

[4] J-M. Siguier, V. Inguimbert, G. Murat, D. Payan and N. Balcon, "Secondary arc mitigation with a RLC circuit coupled with a flashover simulator", proc. of $12^{\text {th }}$ SCTC conf., Kitakyushu, May 14-18, 2012 